\title{
Launching Hong Kong's Healthcare Financing Reform: why continued inaction?
}

\section{G Lieu}

\begin{abstract}
Hong Kong has sought without progress in the past 25 years to introduce reform proposals to enhance the long-term financial sustainability of its healthcare system. Through a systematic review of the consultation documents released over the years, this paper examines what might have been done right or wrong and pinpoints lessons learned for healthcare leaders, executives and reformers facing looming opportunities for reform. The findings suggest that the phased-approach of introducing reform options, involving step-by-step public consultations, to engaging the community to give their views on the healthcare financing reform options has not been effective. Other factors, including changes in the stewardship of the reform initiatives and the top-down elitist-led preparations of pre-launch work, added to the resultant inaction of not taking any
\end{abstract}

of the reform proposals forward for launch and to produce reform. The study proposes that a broadly participatory approach, involving a wider base of members of the community in an inclusive guiding coalition charged to drive the reform from prelaunch to implementation, be undertaken. This coalition should start afresh and, based on renewed evidencebased assessments of the need and urgency of reform, proceed accordingly to formulate, if indicated, an overarching healthcare financing reform agenda that motivates people with conflicting interests to take mutually beneficial actions or that gives stakeholders the right incentives to work effectively together.

Key words: healthcare financing reform; reform strategy and approach; launchreadiness; inclusive coalition.

\section{Geoffrey Lieu}

Founder and Chairman Emeritus

The Insititute for Health Policy and Systems Research Hong Kong

\section{Correspondence:}

geoffrey_lieu@yahoo.com

In his 1995 article 'Leading Change: Why Transformation Efforts Fail', Kotter observed that, of the more than 100 companies that try to remake themselves or to make fundamental changes, 'A few of these corporate change efforts have been very successful. A few have been utter failures. Most fall somewhere in between, with a distinct tilt toward the lower end of the scale.'[1, p.59] Such observations do not seem to be available in healthcare, especially on reforms at the systems level. But it should be safe to assume that such reforms in healthcare, often equally if not much more complex and larger in scale than organisational changes, probably fared no better.
The price of failure can be expensive. It can also have longterm undesirable consequences. The 1986 United States Space Shuttle Challenger disaster and the resultant damage done to NASA and the space shuttle program are vivid examples. This unfortunate incident points to the need to ensure that the right things are done and done right during pre-launch. If not, disastrous results can occur during launch or take-off such that the reform may never be able to reach the planned trajectory. This should be the same in designing and preparing for the launch of healthcare reform initiatives: careful pre-launch planning and preparations are fundamental and deterministic of what follows.

Many reform failures arise from faulty implementation and politics. [2] There is no dearth of analyses on why reforms or transformation efforts fail and how to get them right. $[3,4,5]$ But reports of analyses of reform failures in healthcare appear to be rare. Even fewer seem to have focused on what must need to be done during pre-launch, the preparatory phase, to ensure that the proposed reform is the right thing to do and that a failed or aborted launch will not happen. 
Figure 1: Hong Kong's consultation documents, discussion paper and commissioned studies released since 1991

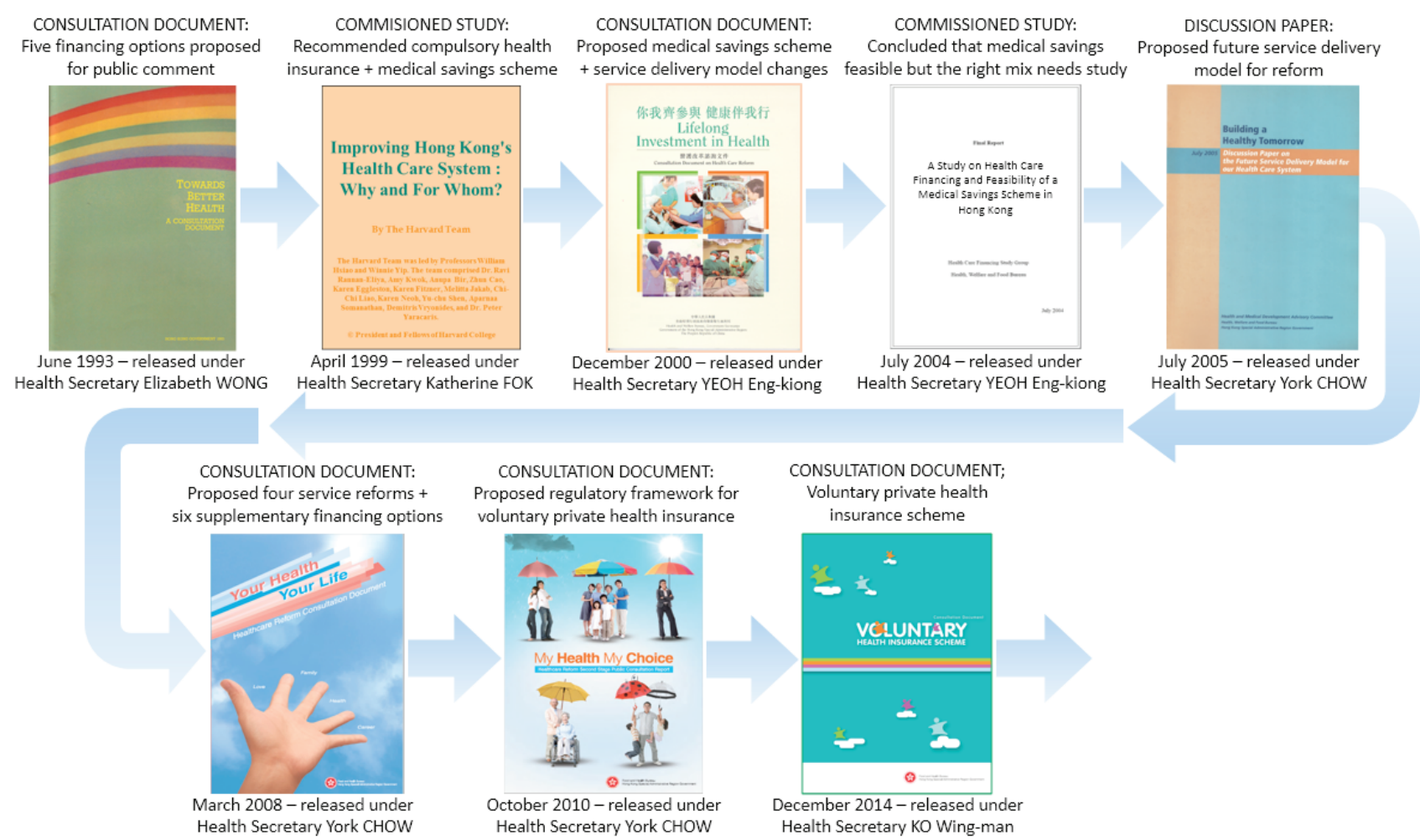

\section{Introduction}

In the past 25 years, since the establishment of the Hospital Authority at the end of 1990 (which represents the only large scale reform that has been implemented in recent decades), the Hong Kong Government has released for public consultation several proposals to reform the healthcare financing system. During this period, which covers 1997, the year when the sovereignty of Hong Kong was returned to China, the healthcare system has come under the oversight of five health secretaries (see Figure 1) serving in four different administrations.

The first consultation was released in 1993, [6] under the British colonial government. But the initiative was not taken forward at the end of the consultation because none or a combination of the options had the general support of the community. [7] After six years of inaction and since 1999, seven more reform proposals, [8-14] in the form of consultation documents or study reports (hereafter, collectively referred to as consultation documents), have been introduced for public consultation. None of them has been taken forward, including the latest one that was released at the end of 2014 and the public consultation of which has already expired 18 months ago.

This pattern of Hong Kong's inaction offers an opportunity to learn about what should or should not be done during the preparatory phase of formulation of the healthcare policy reform agenda. Factors contributing to not taking a reform proposal forward after public consultation should be a meaningful reference to healthcare leaders, reformers and policymakers facing looming opportunities for reform. In addition, the findings could also shed considerable light on the role of Government, the steward of the healthcare system, and on what technical components of reform policy formulation should need to be done or put in place before launch.

\section{Study scope and approach Study questions}

There could be a number of plausible explanations for Hong Kong's inertia or failure to launch the healthcare reform proposals after public consultation. The views of social and political scientists as well as economists are available in the literature $[2,15,16]$ and will be set aside in this paper. Instead, the focus will be on finding answers to the following questions through a systematic review and analysis of all consultation documents released on healthcare financing reform in the past 25 years:

- What approach has been adopted in formulating the healthcare financing reform proposals? Are the leaders and drivers of the process an inclusive or a selected group?

- To what extent has the formulation of reform options or proposals, as maybe discernable in the consultation document, shown use of evidence and involve the 
inclusive participation or input of the community?

- Has the content of the consultation document, when released, provided adequate information and relevant details to denote that the proposals are ready to proceed to launch or launch-ready?

\section{Scope of study}

The review and analysis will be focused on the healthcare financing reform proposals. Those that do not relate to healthcare financing, such as service reforms, are excluded. As the review is on reforms only and to avoid confusion, terms such as change, reform and transformation that are often used interchangeably are clarified as follows:

- Change - The purpose of change is to make something different so as to be different or become something else. This type of change does not require enactment of law or regulatory approval to proceed and can be done well within the ambit of designated or delegated administrative authorities.

- Reform - The purpose of reform is to tackle or improve something by removing or correcting system-wide faults, problems, issues or defects. It usually comes in the form of large scale change in that healthcare providers, users and potential users of healthcare as well as other sectors of society are affected in very substantial ways such that the proposed reform initiatives need to be enacted into law or subject to some form of regulatory approval before proceeding to launch.

- Transformation - Transformation is to change something completely, usually through a composite or a series of changes or reforms. In other words, changes and reforms can lead to transformation, but many do not.

And, changes or reforms do not need to result in a transformation to do good or benefit society or their targeted groups.

Hence, reforms are about policy changes or formulating and implementing proposals to tackle a problem or a group of problems, backed by ordinance enacted or amended. In this regard, a proposal that does not require a policy change or change in ordinance or enactment of subsidiary legislation for implementation will not be defined as reform and will be excluded for review and analysis.

\section{Study approach}

Based on a subject-specific literature review and the underlying thinking and advocacy in the Health-Reform Cycle [5] the Policy Cycle [17] the Operational Framework for Health Policy Analysis [18] and the 8-step Change Process [1,19,20] it is proposed that the following are requisite tasks that should be carried out, using evidence, engaging key stakeholders and involving inclusive community participation, during pre-launch in order to achieve a successful launch and to produce reform:

\section{Problem and Issue Identification}

Reforms are about making improvements or about being better prepared to face future challenges by either correcting current problems or putting in place more effective replacements. Being able to accurately pinpoint critical problems and future issues with evidence, applying lessons learned elsewhere and augmenting them with triangulation of data, methodology or theory are vital. Therefore, the following questions are used to guide the document review:

- Was performance of the current healthcare system assessed and discussed?

- Are critical issues identified and explained?

- Are lessons learned from other healthcare financing systems studied and applied?

- Is the need and urgency of reform explained?

\section{Reform goals and objectives}

After problem and issue identification, the proposal should delineate the policy or guiding principles of reform, the goals, objectives and targets, including resource requirements such as manpower and service capacities, and institutional arrangements to drive or facilitate reform implementation. To the extent that the proposal is about healthcare financing reform, how resources will be allocated or how providers will be paid or incentivised to perform needs to be described. Thus, the following questions are raised in analysing each document's content:

- Are the policy or guiding principles of reform explained?

- Are reform goals, objectives, or targets explained?

- Are resource allocation and provider payment methods outlined?

- Are institutional arrangements augmenting reform implementation outlined?

\section{Analysis of policy options and selection} For any given problem, there could be a number of solutions. Key stakeholders and people affected by the proposed reform will inevitably need to be convinced that the preferred option is the optimal solution Therefore, the following questions need to be fully addressed:

- Are the pros and cons or impact of each reform option explained? 
- Are preferred reform options or design explained?

- Are the rationale or criterial of selecting the proposed options explained?

- Is the feasibility or the resource requirements of achieving the reform goals and objectives discussed?

4. Advocacy and public engagement

Hong Kong has adopted the tradition of public consultations in proposing policy changes since the 1980s. If the process is made inclusive and a meaningful dialogue, it can enrich the information needed to enhance decision-making and to build trust and support for the reform proposal. Hence, engaging key stakeholders and members of the community early in the process and in meaningful forms of participation are essential. The document review will focus on the following questions:

- Are groups or committees involving key stakeholders appointed to give input and advice in the formulation of the reform proposal?

- Are wider community expectations addressed or support mobilised?

- Is a reform engine - a guiding coalition involving informed experts and broad-based community leaders - set up to drive proposal formulation and reform implementation?
Based on the foregoing, an analytical framework (see Figure 2) that outlines the essential work domains, each comprising requisite tasks that should be done, is used to systematically review and analyse the content of the consultation documents. The analysis is about task completion and what was done, not about the effectiveness of how each task was carried out. Tasks unrelated to healthcare financing are not reviewed.

An indicative score of $0,1,2$ or 3 is assigned to each task to show the extent to which work was done or the subject matter was addressed. If the document or report shows evidence that a specific task was performed or additional aspects pursued, indicative scores will be given accordingly as shown in the analytical framework. If no description of the task or subject matter is found, then it will be given an indicative score of zero. In this framework, each task can score only up to a maximum of three points. This is regarded as the theoretical maximum indicative score and implies that the task was completed fully and should contribute maximally to the readiness for launch. Those with a lower score, completing less of what should be done, will contribute less.

Figure 2: Analytical framework and scoring system for assessing the readiness to launch healthcare financil reform proposal

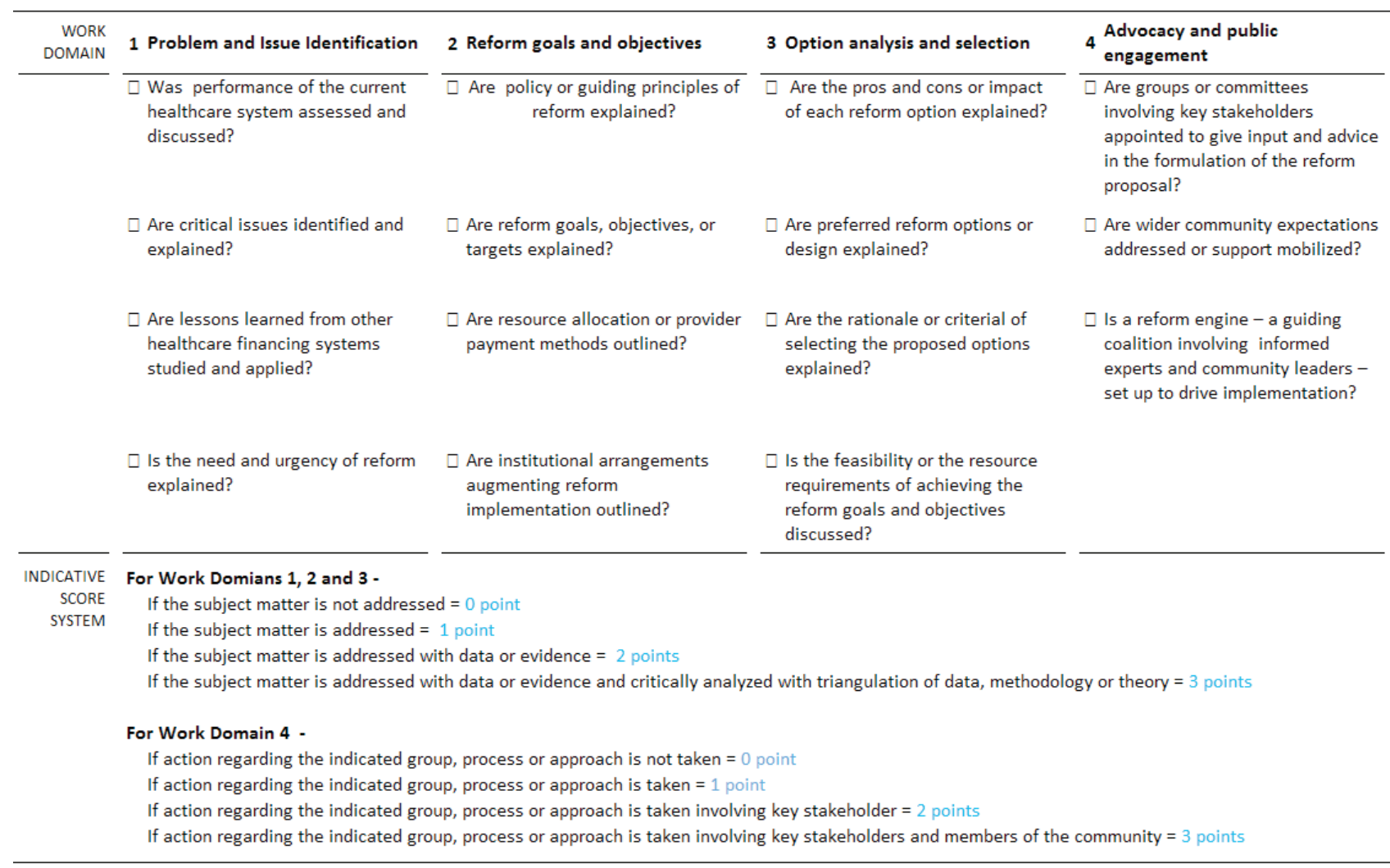


The indicative scores are aggregated and calculated as a proportion of the theoretical maximum indicative scores to produce an index score (maximum $=1.00$ ) to show the launch-readiness of each work domain and the reform proposals as described in the consultation document. An overall index score is calculated for all consultation documents for overview and comparison purposes. While this scoring system is rather crude, it has the advantage of being coded on the basis of clear and simple criteria. It should shed some light and help to explain the extent to which the consultation documents themselves might have contributed or affected the public's views and responses.

\section{Findings}

The consultation documents contain useful information to analyse the strategy adopted to formulate the reform agenda, the principles and objectives of the reform proposals as well as the launch-readiness of the reform proposals. The review presents an opportunity to understand what might have worked and not worked well in Hong Kong's pursuit of seeking to enhance the long-term financial sustainability of its healthcare system and how best to move forward to make better things happen.

\section{Proposal formulation approach}

The first Hong Kong healthcare financing reform proposal in recent history, the Rainbow Document, [6] was released for public consultation in 1993, during the pre-1997 colonial government days. It adopted the new public management approach, made well known by British Prime Minister Margaret Thatcher in the 1970s [21] that sees public involvement as an effective way to engage the community in formulating and implementing reform initiatives. The document put forward a set of reform proposals for public consultation but did not have the general support of the community to move forward. Status quo was preserved. [22] Seven years later and since then, a phased-approach or step-by-step strategy, still involving public consultation to engage the community, was adopted. The approach was first suggested in the Harvard Report [8] and later reiterated in the consultancy document released in 2008. [12] The phased approach intends that, rather than taking the very expensive and time consuming approach of developing each option in detail, the first phase focuses on developing and presenting the principles, basic concepts, key operational details of various options, including pros and cons, in sufficient detail for public consultation. Based on the views received during the first phase consultation, the second phase, mutatis mutandis, involves putting forward detailed proposals, including implementation requirements, for further public consultation. The strategy involves a process of elimination that takes into consideration people's views to identify a most viable option or combination of options from among those developed by the government and a selected few including civic leaders and health professionals. It is topdown and elitist-led, although the community is consulted on bounded options and rationality.

There were two series of the phased-approach. The first series started with the Harvard Report in 1999, [8] followed by a consultation document that presented proposals on service delivery re-organisation and options for financing the healthcare system [9] and ended with without a clear way forward except wide support to the Government's suggestion to conduct further studies on the feasibility of a mandatory medical saving scheme for Hong Kong. [22] A study [10] was completed and report released for consultation near the end of the tenure of the then Health and Welfare Secretary YEOH Eng-kiong. (see again Figure 1).

The second series started in slightly less than one year later in 2005 with the release of a discussion paper [11] that redefined the target populations of public healthcare services and continued until 2010 with yet another document [13] presenting supplementary financing options for public consultation under the stewardship of the immediate past Food and Health Secretary York CHOW. The proposed reform options were directed at enhancing people's financial capacities to seek more private healthcare services and thus allow public hospitals to channel the resources to the disadvantaged and low-income families. [23] There were divergent views on the proposals and none commanded majority support. The government, nevertheless, formulated a voluntary private health insurance scheme, [13] the option with the least public resistence, that was released for public consultation near the end of CHOW's tenure.

In 2014, two years after being appointed to office, the current Food and Health Secretary KO Wing-man released a consultation document [14] that takes forward the private insurance scheme proposed in 2010 with further operational and implementation details. Although it has been nearly 18 months since the end of the public consultation, there is no clear indication yet from the Government about implementation of the latest healthcare financing reform proposal.

In retrospect, the phased approach has not seemed to work out. It has yet to produce a proposal that has broad based community support. There seems to be continuing divergent 
views in the community to whatever was proposed for reform and no majority support is given to any of the financing proposals, notwithstanding the government's persistent message that the long-term sustainability of Hong Kong's healthcare financing system is highly questionable.

\section{Objectives and reform focus of consultation documents}

In line with the phased-approach strategy, the consultation documents, including the reports of the commissioned studies, served primarily as a vehicle to seek public views on the reform principle and a set of proposed options (see Figure 3). Except for the latest document released at the end of 2014, the preceding ones, as intended, were open-ended and not self-contained full reform proposals. The lapse in time between the release of the consultation documents, especially those in the early years, could lead the public to forming a lax impression of the need and urgency of reform. Moreover, not all documents released for public consultation dealt with healthcare financing reform.

Building a Healthy Tomorrow, [11] released in 2005, dealt only with service reforms (see again Figure 3), although the aim was to also strengthen the system's long-term financial sustainability. Three other documents, while focusing on financing reforms, dealt also with service reforms. The rest dealt primarily with healthcare financing reforms and related institutional arrangements, paying little or no attention to service reforms.

It should also be worth noting that the earlier consultation documents focused mainly on the demand-side financing reforms of the public sector while the later ones switched to the private sector. This switch occurred between two health secretaries, denoting perhaps differences in views of where financing reforms could generate the most impact and the public-private adjustment needed to enhance the future financing sustainability of the public system. Whatever the reason, the long lapse in time and the apparent inconsistency in reform focus could distract the public's views of the need and sense of urgency for reform.

Each of the consultation documents identifies a set of system weaknesses or problems to form the basis for proposing the reform options (see Appendix 1). The premise of the need and urgency of reform, as identified in all consultation documents, is based on three main arguments that suggest that the long-term sustainability of the Hong Kong healthcare system is highly questionable:

- Hong Kong's aging population will bring unprecedented pressure both financially and organisationally on the public healthcare system

Figure 3: Healthcare reform objectives and focus of consultation documents

\begin{tabular}{|c|c|c|c|c|c|c|}
\hline \multirow{2}{*}{$\begin{array}{l}\text { YEAR } \\
\text { RELEASE } \\
\text { D }\end{array}$} & \multirow{2}{*}{ TITLE } & \multirow{2}{*}{ OBJECTIVES } & \multicolumn{2}{|c|}{$\begin{array}{l}\text { FINANCING REFORM } \\
\text { FOCUS }\end{array}$} & \multicolumn{2}{|c|}{$\begin{array}{l}\text { SERVICE REFORM } \\
\text { FOCUS }\end{array}$} \\
\hline & & & $\begin{array}{l}\text { Public } \\
\text { Sector }\end{array}$ & $\begin{array}{l}\text { Private } \\
\text { sector }\end{array}$ & $\begin{array}{l}\text { Public } \\
\text { Sector }\end{array}$ & $\begin{array}{l}\text { Private } \\
\text { Sector }\end{array}$ \\
\hline 1993 & $\begin{array}{l}\text { Towards Better Health: A Consultation } \\
\text { Document (The Rainbow Document) }\end{array}$ & $\begin{array}{l}\text { To seek public views on five financing options. The underlying premise } \\
\text { is that the financing of the heavily subsidized public healthcare is } \\
\text { unsustainable. }\end{array}$ & $\sqrt{ }$ & & & \\
\hline 1999 & $\begin{array}{l}\text { Improving Hong Kong's Health Care } \\
\text { System: Why and For Whom? (The } \\
\text { Harvard Report) 1st Stage Consultation }\end{array}$ & $\begin{array}{l}\text { The consultancy study deals with the financing and organization of } \\
\text { health care in Hong Kong. It proposes five services improvement options } \\
\text { and recommends social health insurance and a medical savings scheme }\end{array}$ & $\sqrt{ }$ & & $\sqrt{ }$ & \\
\hline 2000 & $\begin{array}{l}\text { Lifelong Investment in Health: } A \\
\text { Consultation Document on Health Care } \\
\text { Reform } \quad \text { 2nd Stage }\end{array}$ & $\begin{array}{l}\text { To seek public views on a package of reform proposals on service } \\
\text { delivery, quality assurance and a mandatory medical savings } \\
\text { scheme. The document represents the } 2 \text { nd stage consultation where the }\end{array}$ & $\sqrt{ }$ & & $\sqrt{ }$ & \\
\hline 2004 & $\begin{array}{l}\text { A Study on Health Care Financing and } \\
\text { Feasibility of a Medical Savings Scheme } \\
\text { in Hong Kong }\end{array}$ & $\begin{array}{l}\text { To examine the merits or otherwise of a mandatory medical savings } \\
\text { scheme, based on international examples and lessons, and its feasibility } \\
\text { for application in Hong Kong. }\end{array}$ & $\sqrt{ }$ & & & \\
\hline 2005 & $\begin{array}{l}\text { Building a Healthy Tomorrow: Discussion } \\
\text { Paper on the Future Service Delivery } \\
\text { Model for our Health Care System }\end{array}$ & $\begin{array}{l}\text { To seek public support on instituting a new service delivery model for } \\
\text { achieving a sustainable healthcare system. The document is about } \\
\text { service delivery reform, NOT financing reform. }\end{array}$ & n.a. & n.a. & $\checkmark$ & $\sqrt{ }$ \\
\hline 2008 & $\begin{array}{l}\text { Your Health Your Life: Healthcare } \\
\text { Reform Consultation Document } \\
\text { 1st Stage Consultation }\end{array}$ & $\begin{array}{l}\text { To consult the public, as the first of a two-stage process, on the key } \\
\text { principles and concepts of service reforms and the pros and cons of six } \\
\text { supplementary financing options. }\end{array}$ & & $\sqrt{ }$ & $\sqrt{ }$ & \\
\hline 2010 & $\begin{array}{l}\text { My Health My Choice: Healthcare } \\
\text { Reform Second Stage Consultation } \\
\text { Document } 2 \text { 2nd Stage Consultation }\end{array}$ & $\begin{array}{l}\text { To consult, as second stage consultation, the public on the features and } \\
\text { requirements of the proposed voluntary supplementary healthcare } \\
\text { financing scheme, a standardized and regulated framework for private }\end{array}$ & & $\sqrt{ }$ & & \\
\hline 2014 & $\begin{array}{l}\text { Voluntary Health Insurance Scheme: } \\
\text { Consultation Document }\end{array}$ & $\begin{array}{l}\text { To take forward the voluntary supplementary healthcare scheme, as } \\
\text { outlined in the consultation document My Health My Choice, under the } \\
\text { new name of Voluntary Health Insurance Scheme (VHIS). }\end{array}$ & & $\sqrt{ }$ & & \\
\hline
\end{tabular}


- The current public healthcare system is overloaded and over-stretched

- Rising public expectation of healthcare services and increasing medical costs.

Yet, the proposed reform options put forward in each consultation document to address these issues varied: from social health insurance to voluntary private health insurance, from mandatory medical savings to personal health reserve, and from capping government budget to raising user fees. This could be confusing to the public and thus lead to none of them commanding a majority consensus in the community.

Additionally, the financing reforms proposed thus far are focused mainly on the demand side. Very little seems to have been considered or proposed on the supply side. How to pay providers can be incentives or disincentives affecting provider behavior. It is a fundamental and complex issue in healthcare. Not addressing upfront the supply side of the financing equation fully and concurrently in healthcare financing reform proposal could create uncertainties and doubts in both the minds of providers and users that may not be warranted.

This raises a point that, while formulating the healthcare reform agenda, one should consider broadly from a systemwide perspective and understand deeply the needs for service, financing and management reforms and plan strategically for a reform agenda that clearly delineates launch priority (see Figure 4). As no part of the system is unlinked, implementing reform in one area without a conjoint plan of action in the others will unlikely yield the best results or achieve the most benefits. Knowing the control knobs of the system and having a clear sense of how they interact and function can guide the setting of focus and priorities in the reform agenda. Once the focus and priorities of reform are confirmed, concentrated efforts could then be directed at identifying the right timing to launch and thrust the reform into orbit.

The constraints affecting Hong Kong's heathcare financing reform should be madeexplicit. Unique to Hong Kong, there are three factors, not always made known in the consultation documents, that can affect the range of options that may be considered for reform:

- The Basic Law specifies a principle for government budget in that the expenditure and the revenue should be balanced, budget deficit is to be avoided, and the budget should be kept commensurate with the growth rate of Hong Kong's gross domestic product. [24]

- The government currently limits the estimated recurrent expenditure on health to not exceed 17 percent of the government's total annual recurrent expenditure. In 2016-17, the share is 16.5 percent. [25]

Figure 4: Identifying priority areas for a conjoint reform agenda

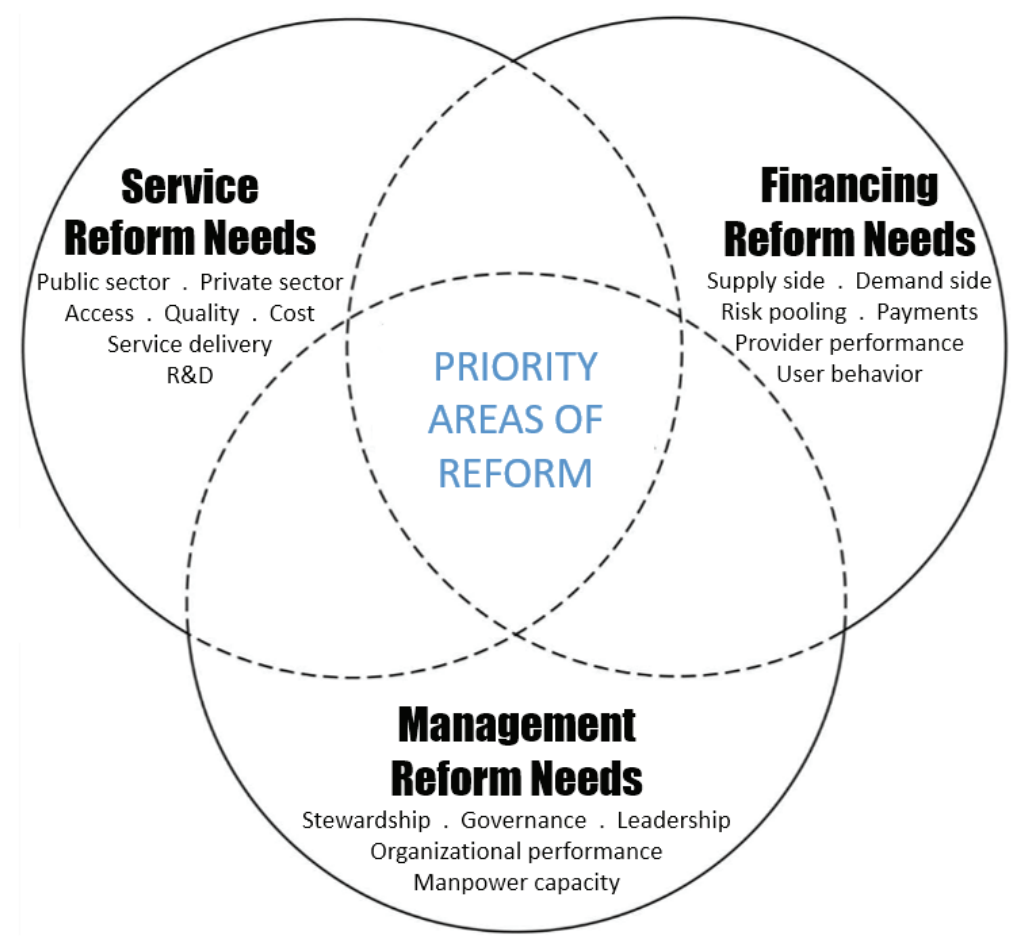


- There are ongoing high expectations on the demand side and the government has repeatedly reiterated that it will continue to adhere to the long-held principle that 'no person should be prevented, through lack of means, from obtaining adequate medical treatment' [26] and to uphold the public healthcare system as the safety net for the whole population. [13]

These three factors should be made explicit as they can impose enormous pressure and constrains on the system. But the challenge and reward of course is how to turn them into opportunities.

\section{The launch readiness of the reform proposals}

As a group, the past consultation documents have an overall launch-readiness index of only 0.46 out of the maximum of 1.00 (see Figure 5). With exception of the Harvard Report [8] that has an acceptable rating, all consultation documents have only marginal or unimpressive launch-readiness index scores. This suggests that the consultation documents might not have provided adequate information to the extent that justify taking them forward to launch. In other words, if a consultation document with a marginal or low index score is released for public consultation, the likelihood of it commanding a majority support should be low. Indeed, none or a combination of the proposals in the consultation documents commanded a majority support and was not taken forward.

The study results show that the consultation documents did a marginal job in Problem and Issue Identification and in Analysis of Policy Options and Selection but poorly in Reform Goals and Objectives and in Advocacy and Public Engagement (see again Figure 5). Two questions should need to be raised: (1) what contributed to the poor index scores, and (2) why even a high index score did not have support of the community.

The low index score in Reform Goals and Objectives was due primarily to the absence or inadequate description of how resources will be allocated or how providers will be paid under the reformed healthcare financing system (see

Figure 5: Launch-readiness index of reform options or proposals as presented in the consultation documents (full readiness $=1.00$ )

\begin{tabular}{|c|c|c|c|c|c|c|c|c|c|c|c|c|c|c|c|c|}
\hline \multirow[b]{3}{*}{$\begin{array}{c}\text { YEAR } \\
\text { RELEASED }\end{array}$} & \multirow[b]{3}{*}{ DOCUMENT OR STUDY TITLE } & & & & \multicolumn{6}{|c|}{ WORK DOMAIN } & & & & & & \\
\hline & & \multicolumn{3}{|c|}{$\begin{array}{l}\text { 1. PROBLEM AND ISSUE } \\
\text { IDENTIFICATION }\end{array}$} & \multicolumn{3}{|c|}{$\begin{array}{l}\text { 2. REFORM GOALS AND } \\
\text { OBJECTIVES }\end{array}$} & \multicolumn{3}{|c|}{$\begin{array}{l}\text { 3. ANALYSIS OF POLICY } \\
\text { OPTIONS \& SELECTION }\end{array}$} & \multicolumn{3}{|c|}{$\begin{array}{l}\text { 4. ADVOCACY AND } \\
\text { PUBLIC ENGAGEMENT }\end{array}$} & \multicolumn{3}{|c|}{ ALL DOMAINS } \\
\hline & & 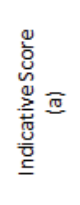 & 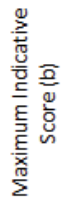 & 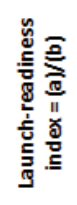 & 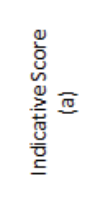 & 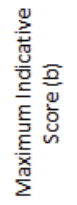 & 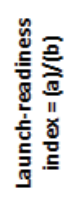 & 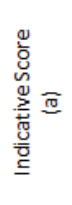 & 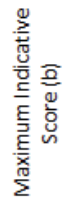 & 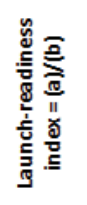 & 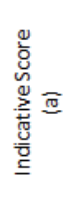 & 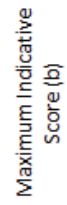 & 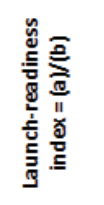 & 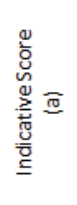 & 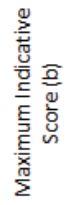 & 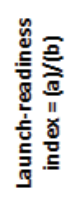 \\
\hline 1993 & $\begin{array}{l}\text { Towards Better Health: A Consultation } \\
\text { Document (The Rainbow Document) }\end{array}$ & 6 & 12 & 0.50 & 3 & 12 & 0.25 & 5 & 12 & 0.42 & 2 & 9 & 0.22 & 16 & 45 & 0.36 \\
\hline 1999 & $\begin{array}{l}\text { Improving Hong Kong's Health Care } \\
\text { System: Why and For Whom? (The } \\
\text { Harvard Report) 1st Stage Consultation }\end{array}$ & 10 & 12 & 0.83 & 6 & 12 & 0.50 & 11 & 12 & 0.92 & 5 & 9 & 0.56 & 32 & 45 & 0.71 \\
\hline 2000 & $\begin{array}{l}\text { Lifelong Investment in Health: A } \\
\text { Consultation Document on Health Care } \\
\text { Reform } \quad \text { 2nd Stage Consultation }\end{array}$ & 4 & 12 & 0.33 & 3 & 12 & 0.25 & 3 & 12 & 0.25 & 2 & 9 & 0.22 & 12 & 45 & 0.27 \\
\hline 2004 & $\begin{array}{l}\text { A Study on Health Care Financing and } \\
\text { Feasibility of a Medical Savings Scheme in } \\
\text { Hong Kong }\end{array}$ & 8 & 12 & 0.67 & 4 & 12 & 0.33 & 8 & 12 & 0.67 & 4 & 9 & 0.44 & 24 & 45 & 0.53 \\
\hline 2005 & $\begin{array}{l}\text { Building a Healthy Tomorrow: Discussion } \\
\text { Paper on the Future Service Delivery } \\
\text { Model for our Health Care System }\end{array}$ & & & & The stud & dy is abou & ut service & delivery & reform & , NOT he & Ithcare & financi & ng reform. & & & \\
\hline 2008 & $\begin{array}{l}\text { Your Health Your Life: Healthcare Reform } \\
\text { Consultation Document } \\
\text { 1st Stage Consultation }\end{array}$ & 8 & 12 & 0.67 & 3 & 12 & 0.25 & 6 & 12 & 0.50 & 2 & 9 & 0.22 & 19 & 45 & 0.42 \\
\hline 2010 & $\begin{array}{l}\text { My Health My Choice: Healthcare Reform } \\
\text { Second Stage Consultation Document } \\
\text { 2nd Stage Consultation }\end{array}$ & 8 & 12 & 0.67 & 4 & 12 & 0.33 & 6 & 12 & 0.50 & 2 & 9 & 0.22 & 20 & 45 & 0.44 \\
\hline 2014 & $\begin{array}{l}\text { Voluntary Health Insurance Scheme: } \\
\text { Consultation Document }\end{array}$ & 8 & 12 & 0.67 & 7 & 12 & 0.58 & 6 & 12 & 0.50 & 2 & 9 & 0.22 & 23 & 45 & 0.51 \\
\hline & ALL DOCUMENTS & 52 & 84 & 0.62 & 30 & 84 & 0.36 & 45 & 84 & 0.54 & 19 & 63 & 0.30 & 146 & 315 & 0.46 \\
\hline
\end{tabular}


Appendix 3). This is a critical issue that both providers and users of healthcare are concerned about. It is probably also the most important consideration in any healthcare financing system or reform. How funds and financial resources are pooled and how providers are paid will affect how providers and users of healthcare services will behave. Unfortunately, this is an item that the reform options or proposals seem to have ignored or not given the needed attention deserved. Another contributing factor is the lack of adequate description about the institution arrangements that will be put in place to augment reform implementation. People should want to know how they will be affected under the proposed healthcare financing system. And, the roles and responsibilities of these institutional arrangements and how they will function could affect people's confidence as well.

Advocacy and Public Engagement has the lowest index score among all four work dimensions. The low index score was mainly due to two factors: (1) wider community expectations of the reform were either not well addressed or community support not mobilised; and (2) a reform engine, such as a guiding coalition, to drive implementation was not set up with inclusive participation (see Appendix 5). This suggest that wider community expectations, not just those of key stakeholders, must be well understood and their support mobilised while formulating the reform options or proposals. In this regard, involvement of trusted and respected individuals from among key stakeholders and members of the community, in addition to government officials and individuals appointed to government task forces or committees should be important.

The Harvard Report [8] received the highest index score relative to all other consultation documents but the proposals were not taken forward. Two factors possibly contributed to this outcome: (1) the mechanism and effects of resource allocation and provider payment methods were not detailed; and (2) wider community expectations were not adequately addressed or support of the proposed options not mobilised (see Appendixes 3 and 5). The report, however, was not well received by the public. [22] This points to the importance and need for reform proposals to be aligned or not depart from society's values and norms. The Harvard Report [8] seems to have ignored these elements and proposes a social insurance system plus a mandatory savings scheme that represent a complete paradigm shift from Hong Kong's long-held tax-funded financing system. The proposals build not on the strengths of the Hong Kong system but on concepts that seem to work elsewhere and are not tested locally. The proposals represent so drastic a transformation that key stakeholders and people are unwilling to undertake and, thus, the rejection. This is one of the most important lessons that should be learned about formulating healthcare financing reform proposals or options.

In sum, the low index scores suggest that the consultation documents have not provided total information or convincing evidence and have not fully addressed the critical issues of concern to the extent of commanding a majority support of key stakeholders and the community. And, with the successive inaction following public consultation, available options for reform are becoming limited. It also makes reformulation of previously introduced proposals nearly impossible, at least politically. This raises a question about the appropriateness of the phasedapproach and what reform approach should be put in its place in future.

Based on the Hong Kong experience, it should be unwise to release any reform option or proposal for public consultation unless all available evidence have been put to use, people's issues and concerns are well understood and addressed, viable options or proposals are field tested and reformulated if indicated. Furthermore, given that the purpose of the consultation document is a policy advocacy and public communication medium, the content must address the concerns of key stakeholders and the reform proposals should be formulated based on acceptable values and norms of society as well as strengths of the current system.

\section{Conclusion}

Hong Kong's 25-year long journey in pursuit of a healthcare financing reform option does not seem to have been productive: the past consultation documents are mostly not launch-ready and there is still no majority support for a reform proposal to tackle the inevitable financing problems that the system seems to be facing. Valuable time has been lost and must be prevented from happening again in future.

The phased-approach seems to have been more of an inhibitor rather than a facilitator because people are asked step-by-step to give input on the reform options or proposls or show their preferences based on limited choices and details that may be inadequate to make informed choices. The phased-approach could be disruptive and show disconnect between health secretaries who are stewards of the reform initiatives. The reform focus had actually shifted when a new health secretary comes on board. The delays in between proposals could have created an impression in the 
minds of the public that the sense of urgency is not real. Over the years there have been many consultation documents and as each of them proposes different options to address essentially similar problems, the public must be bewildered.

People need to be convinced that Hong Kong's healthcare financing system needs urgent reform. Past reform proposals often lack contestable evidence to take on key stakeholder challenges. The consultation document is an important medium not only of communication but also a presentation of the roadmap of how the new system will function, how providers and users will be affected and what gains or benefits will be achieved individually and for society. The consultation documents in the past have largely not addressed these questions adequately. The future consultation document, when released, must need to convince the public that the proposals have community support and the reform will be driven by people whom the community trusts and respects and are ready for launch.

The consultation documents have largely been developed under the health secretary's leadership and driven by government appointed individuals or Hong Kong's elites. Except for consultants conducting surveys in the community or focus groups of key stakeholders for some of the consultation documents, involvement of users of healthcare and members of the community is infrequent if at all. To get the job done better, a broadly participatory approach should be adopted. It should involve members of the broader community in an inclusive guiding coalition charged to drive the healthcare financing reform from prelaunch to implementation. This coalition should start afresh and, based on renewed evidence-based assessments of the need and urgency of reform, proceed accordingly to formulate an overarching reform proposal that motivates people with conflicting interests to take mutually beneficial actions or that gives stakeholders the right incentives to work effectively together.

Moreover, the study findings of Hong Kong's healthcare financing reform journey denote something more worrisome. Seventeen years ago the Harvard Report pointed out that'the Hong Kong government lacks sufficient capacity, competency, and information to set sound health policy and monitor its execution'. [8, p.8] These observations and unwelcomingly critical comments, unfortunately, seem to remain valid even today.

Hong Kong needs to overhaul its approach in healthcare systems and financing reform. To get things right and to make things happen, Hong Kong needs a strong inclusive guiding coalition to take things forward. It needs a well coordinated inclusive and participatory approach. It needs to involve more knowledgeable experts with information and institutional capacity to conduct objective and rational analysis and to monitor the system's performance. It needs to involve the community and key stakeholders early on as partners in search of solutions and in building up broadbased support for the subsequent reform launch and to produce reform. It needs more competent and highly motivated leaders and healthcare executives who have deep understanding of the community, the meaning of health to individuals and society and the nature of the business of healthcare to take things forward. They need to have the initiative, sincerity, not rhetorical commitment, and capacity to lead, impact and do good for people and the system. The Hong Kong healthcare system needs to quickly catch up with steadfast vigor.

\section{Competing interests}

The author declares that he has no competing interests.

\section{References}

1. Kotter J. Leading change: why transformation efforts fail. Harvard Business Review. 1995; March-April.

2. Schuck P. Why government fails so often: and how it can do better. Princeton: Princeton University Press; 2015.

3. Kotter P. Leading change: why transformation efforts fail. Harvard Business Review. 2007; Jan.

4. Isern J, Pung C. Driving radical change. McKinsey Quarterly. 2007;(4). Available from: http://www.mckinsey.com/businessfunctions/organization/ourinsights/driving-radical-change .

5. Roberts M. et al. Getting health reform right: a guide to improving performance and equity. Oxford: Oxford University Press; 2008.

6. Health and Welfare Bureau. Towards Better Health. Hong Kong: Hong Kong Government Printing Office; 1993.

7. Panel on Health Services. Health Care Reform. LC Paper No. CB(2)2252/04-05(01). Hong Kong: Legislative Council, Hong Kong Special Administrative Region Government; 13 July 2005.

8. The Harvard Team. Improving Hong Kong's health care system: why and for whom? Boston: President and Fellows of Harvard College; 1999.

9. Health and Welfare Bureau. Lifelong investment in health. Hong Kong: Hong Kong Special Administrative Region Government; 2000.

10. Health, Welfare and Food Bureau. A study on health care financing and feasibility of a medical savings scheme in Hong Kong. Hong Kong: Hong Kong Special Administrative Region Government; July 2004

11. Health, Welfare and Food Bureau. Building a Healthy Tomorrow: Discussion Paper on the Future Service Delivery Model for our Health Care System. Hong Kong: Hong Kong Special Administrative Region Government; July 2005.

12. Food and Health Bureau. Your Health Your Life: Report on First Stage Public Consultation on Healthcare Reform. Hong Kong: Hong Kong Special Administrative Region Government; December 2008. 
13. Food and Health Bureau. My Health My Choice: Healthcare Reform Second Stage Public Consultation Document. Hong Kong: Hong Kong Special Administrative Region Government; October 2010.

14. Food and Health Bureau. Voluntary Health Insurance Scheme Consultation Document. Hong Kong: HKSAR;. December 2014.

15. Hay J. Health care in Hong Kong: an economic policy assessment. Hong Kong: The Chinese University Press; 1992.

16. Tompson W. The political economy of reform: lessons from pensions, product markets and labour markets in Ten OECD countries. OECD; 2009. Available from: http://www.oecd.org/site/sgemrh/ 46190166.pdf

17. Benoit $F$, Jacques M. Public policy models and their usefulness in public health: the stages model. Québec: National Collaboration Centre for Healthy Public Policy; 2013. Available from: http://www. ncchpp.ca/docs/ModeleEtapesPolPubliquesEN.pdf

18. de Araújo Jr, José L, Romolu M. Developing an operational framework for healthy policy analysis. Revista Brasileira de Saúde Materno Infantil, Recife. (The Brazilian Journal of Mother and Child Health). 2001;1(3):203-221, set.-dez., 2001. Available from: http:// www.scielo.br/pdf/rbsmi/v1n3/v1n3a02.pdf

19. Kotter J. Accelerate: building strategic agility for a fast moving world. Harvard Business Review Press. 2014.

20. Kajimbwa M. New public management: a tribute to Margaret Thatcher. Public Policy and Administration Research. 2013;3(5): 64-69, Available from: http://www.iiste.org/Journals/index.php/ PPAR/article/viewFile/5554/5667

21. LegCo Panel on Health Services. Studies on Health Care Financing and Feasibility of a Medical Savings Scheme in Hong Kong. Paper No. CB(2)2692/03-04(03). Hong Kong: Legislative Council, Hong Kong Special Administrative Region Government; 14 June 2004. Available from: http://www.legco.gov.hk/yr03-04/ english/panels/ hs/papers/hs0614cb2-2692-3e.pdf

22. Food and Health Bureau. My Health My Choice: Healthcare Reform Second Stage Public Consultation Report. Hong Kong: Hong Kong Special Administrative Region Government; July 2011.

23. Basic Law of the Hong Kong Special Administrative Region of the People's Republic of China, Article 107. 1 July 1997. Available from: http://www.basiclaw.gov.hk/en/ basiclawtext/index.html

24. Finance Secretary. The 2016-17 Budget. Hong Kong:Hong Kong Special Administrative Region Government; 2016.

25. Hospital Authority Ordinance, Cap 113, s 4 (d). 30 June 1997 (Enacted 1990). 
Appendix 1: System weaknesses and reform options proposed for consultation

\begin{tabular}{|c|c|c|c|}
\hline $\begin{array}{l}\text { YEAR } \\
\text { RELEASED }\end{array}$ & TITLE & SYSTEM WEAKNESSES OR PROBLEMS & REFORM OPTIONS OR PROPOSALS \\
\hline 1993 & $\begin{array}{l}\text { Towards Better Health: } \\
\text { A Consultation Document } \\
\text { (The Rainbow Document) }\end{array}$ & $\begin{array}{l}\text { - Overloading" } \\
\text { - Manpower constraints } \\
\text { - Inequitable fee structure } \\
\text { - Lack of choice } \\
\text { - Lack of interface }\end{array}$ & $\begin{array}{l}\text { The existing policy that no one should be denied adequate medical } \\
\text { treatment through lack of means will remain paramount." PLUS } \\
\text { The following proposals for consultation: } \\
\text { - Percentage subsidy approach } \\
\text { - Target group approach } \\
\text { - Co-ordinated voluntary insurance } \\
\text { - Compulsory comprehensive insurance } \\
\text { - Prioritization of treatment approach }\end{array}$ \\
\hline 1999 & $\begin{array}{l}\text { Improving Hong Kong's Health } \\
\text { Care System: Why and For Whom? } \\
\text { (The Harvard Report) } \\
\text { 1st Stage Consultation } \\
\text { - }\end{array}$ & $\begin{array}{l}\text { A policy of benign neglect has left Hong Kong without } \\
\text { a coherent overall policy for financing and organizing } \\
\text { health care that: } \\
\text { - The healthcare system is highly compartmentalized } \\
\text { The quality of care is highly variable, particularly } \\
\text { in the private sector } \\
\text { - The financial and organizational sustainability are } \\
\text { highly questionable }\end{array}$ & $\begin{array}{l}\text { "Every resident should have access to reasonable quality and } \\
\text { affordable health care. The government assures this access through } \\
\text { a system of shared responsibility between the government and } \\
\text { residents where those who can afford to pay for health care should } \\
\text { pay." PLUS } \\
\text { The following proposals for consultation: } \\
\text { - Status quo } \\
\text { - Cap government budget on health } \\
\text { - Raise user fees with exemptions } \\
\text { - Health Security Plan (social health insurance) and MEDISAGE } \\
\text { (mandatory medical savings) } \\
\text { - Competitive Integrated Health Care }\end{array}$ \\
\hline 2000 & $\begin{array}{l}\text { Lifelong Investment in Health: } \\
\text { A Consultation Document on } \\
\text { Health Care Reform } \\
\text { 2nd Stage Consultation }\end{array}$ & $\begin{array}{l}\text { The following main pillars are unable to meet the needs } \\
\text { and aspirations of Hong Kong's future generations: } \\
\text { - Organization and provision of health services } \\
\text { - Healthcare quality assurance mechanisms } \\
\text { - Funding and financing for healthcare services }\end{array}$ & $\begin{array}{l}\text { "We must continue to uphold our long-held policy of ensuring that no } \\
\text { one is denied adequate medical care because of insufficient means." } \\
\text { PLUS } \\
\text { The following proposals for consultation: } \\
\text { - Reduce costs } \\
\text { - Revamp fee structure } \\
\text { - Establish Health Protection Accounts (mandatory medical savings) }\end{array}$ \\
\hline 2004 & $\begin{array}{l}\text { A Study on Health Care Financing } \\
\text { and Feasibility of a Medical } \\
\text { Savings Scheme in Hong Kong }\end{array}$ & $\begin{array}{l}\text { - Need to address post retirement health care } \\
\text { expenditure } \\
\text { - Need rigorous cost-containment measures in the } \\
\text { public system } \\
\text { - Need to ensure resources can be targeted to patients } \\
\text { and services of the greatest needs }\end{array}$ & $\begin{array}{l}\text { The study demonstrated that it is feasible to introduce a medical } \\
\text { savings scheme in Hong Kong. But the Government noted that it will } \\
\text { need to examine carefully the role of a medical savings scheme and } \\
\text { how it will complement other measures as well as the detailed } \\
\text { features of such a scheme in addition to taking into account the } \\
\text { feedback and comments from key stakeholders and the community. } \\
\text { The Government reiterated in the study report that "we will maintain } \\
\text { our long-established principle that no one will be denied appropriate } \\
\text { medical care due to lack of means." }\end{array}$ \\
\hline 2005 & $\begin{array}{l}\text { Building a Healthy Tomorrow: } \\
\text { Discussion Paper on the Future } \\
\text { Service Delivery Model for our } \\
\text { Health Care System }\end{array}$ & $\begin{array}{l}\text { - Over-reliance on the heavily subsidized public } \\
\text { healthcare system } \\
\text { - An aging population } \\
\text { - Tendency of early occurrence of chronic illnesses } \\
\text { in the population resulting in prolonged reliance } \\
\text { on the public system } \\
\text { - Advancement in medical technology leading to } \\
\text { increasing number of treatable medical conditions } \\
\text { at high costs } \\
\text { - Over-stretched hospital services }\end{array}$ & $\begin{array}{l}\text { Future service delivery model outlined (not intended to be } \\
\text { a healthcare financing reform proposal) }\end{array}$ \\
\hline 2008 & $\begin{array}{l}\text { Your Health Your Life: Healthcare } \\
\text { Reform Consultation Document } \\
\text { 1st Stage Consultation }\end{array}$ & $\begin{array}{l}\text { - Public hospital services at risk, arising from the } \\
\text { elderly population and increasing occurrence } \\
\text { of lifestyle-related diseases } \\
\text { - Health expenditure rising at a much faster pace than } \\
\text { the economy } \\
\text { - Limited alternative choice to public hospital services } \\
\text { - Patient safety net not wide enough } \\
\text { - Insufficient emphasis on holistic primary care } \\
\text { - Limited continuity and integration of care }\end{array}$ & $\begin{array}{l}\text { "We will continue to uphold the treasured principle of our healthcare } \\
\text { policy that no one should be denied adequate healthcare through lack } \\
\text { of means" } P \text { LUS } \\
\text { The following proposals for consultation: } \\
\text { - Social health insurance } \\
\text { - Out of pocket payments (user fees) } \\
\text { - Medical savings accounts } \\
\text { - Voluntary private health insurance } \\
\text { - Mandatory private health insurance } \\
\text { - Personal health reserve }\end{array}$ \\
\hline
\end{tabular}




\section{Appendix 1: System weaknesses and reform options proposed for consultation continued}

\begin{tabular}{|c|c|c|c|}
\hline $\begin{array}{l}\text { YEAR } \\
\text { RELEASED }\end{array}$ & TITLE & SYSTEM WEAKNESSES OR PROBLEMS & REFORM OPTIONS OR PROPOSALS \\
\hline 2010 & $\begin{array}{l}\text { My Health My Choice: Healthcare } \\
\text { Reform Second Stage Consultation } \\
\text { Document } \\
\text { 2nd Stage Consultation }\end{array}$ & $\begin{array}{l}\text { - The public system and hence the system as a whole } \\
\text { are unsustainable } \\
\text { - Need to enhance the sustainable development of the } \\
\text { private healthcare sector }\end{array}$ & $\begin{array}{l}\text { "We will continue to uphold the public healthcare system as the safety } \\
\text { net for the whole population." PLUS } \\
\text { The following proposals for consultation: } \\
\text { - Voluntary private health insurance (Health Protection Scheme, } \\
\text { a standardized and regulated framework for health insurance) } \\
\text { as supplementary financing } \\
\text { - The Government pledges to draw HK\$50 billion from the fiscal } \\
\text { reserve to support reform. }\end{array}$ \\
\hline 2014 & $\begin{array}{l}\text { Voluntary Health Insurance } \\
\text { Scheme: Consultation Document }\end{array}$ & $\begin{array}{l}\text { - Faces challenges of an aging population, rising public } \\
\text { expectation of healthcare services and increasing } \\
\text { medical costs } \\
\text { - Need to identify suitable measures to improve quality } \\
\text { of healthcare services } \\
\text { - Need to readjust the public-private balance so as to } \\
\text { maintain the system's long-term sustainability }\end{array}$ & $\begin{array}{l}\text { "The Government will continue to uphold the dual track healthcare } \\
\text { "The Government will continue to uphold the dual track healthcare } \\
\text { system and strengthen its commitment to the sustainable development } \\
\text { of public system as the safety net for all." } \\
\text { With reference to the deliberation by the Working Group and the } \\
\text { Consultant's recommendations, this Document sets forth the detailed } \\
\text { proposals for implementing the Voluntary Health Insurance Scheme, } \\
\text { a regulated individual indemnity hospital insurance, for public } \\
\text { consultation. }\end{array}$ \\
\hline
\end{tabular}

Appendix 2: Indicative and index scores of tasks performance under work domain - problem

\begin{tabular}{|c|c|c|c|c|c|c|c|c|}
\hline \multirow[b]{2}{*}{$\begin{array}{c}\text { YEAR } \\
\text { RELEASED }\end{array}$} & \multirow[b]{2}{*}{ TITLE } & \multicolumn{7}{|c|}{ 1. PROBLEM AND ISSUE IDENTIFICATION } \\
\hline & & $\begin{array}{l}\text { PERFORMANCE } \\
\text { OF CURRENT } \\
\text { SYSTEM } \\
\text { ASSESSED AND } \\
\text { DISMISSED }\end{array}$ & $\begin{array}{l}\text { CRITICAL } \\
\text { ISSUES } \\
\text { IDENTIFIED AND } \\
\text { EXPLAINED }\end{array}$ & $\begin{array}{l}\text { LESSONS FROM } \\
\text { OTHER } \\
\text { HEALTHCARE } \\
\text { SYSTEMS } \\
\text { STUDIED AND } \\
\text { APPLIED }\end{array}$ & $\begin{array}{l}\text { NEED AND } \\
\text { URGENCY OF } \\
\text { REFORM } \\
\text { EXPLAINED }\end{array}$ & $\begin{array}{l}\text { INDICATIVE } \\
\text { SCORES }\end{array}$ & $\begin{array}{l}\text { MAXIMUM } \\
\text { INDICATIVE } \\
\text { SCORES }\end{array}$ & $\begin{array}{l}\text { LAUNCH } \\
\text { READINESS } \\
\text { INDEX }\end{array}$ \\
\hline 1993 & $\begin{array}{l}\text { Towards Better Health: A Consultation Document } \\
\text { (The Rainbow Document) }\end{array}$ & 2 & 2 & 1 & 1 & 6 & 12 & 0.50 \\
\hline \multirow[t]{2}{*}{1999} & $\begin{array}{l}\text { Improving Hong Kong's Health Care System: } \\
\text { Why and For Whom? (The Harvard Report) }\end{array}$ & & & & & & & \\
\hline & 1st Stage Consultation & 3 & 2 & 3 & 2 & 10 & 12 & 0.83 \\
\hline 2000 & $\begin{array}{l}\text { Lifelong Investment in Health: A Consultation Document } \\
\text { on Health Care Reform 2nd Stage Consultation }\end{array}$ & 1 & 2 & 0 & 1 & 4 & 12 & 0.33 \\
\hline 2004 & $\begin{array}{l}\text { A Study on Health Care Financing and Feasibility } \\
\text { of a Medical Savings Scheme in Hong Kong }\end{array}$ & 2 & 1 & 3 & 2 & 8 & 12 & 0.67 \\
\hline 2005 & $\begin{array}{l}\text { Building a Healthy Tomorrow: Discussion Paper on the } \\
\text { Future Service Delivery Model for our Health Care System }\end{array}$ & \multicolumn{7}{|c|}{$\begin{array}{l}\text { The document is not analyzed because it is about service delivery reform, } \\
\text { NOT healthcare financing reform. }\end{array}$} \\
\hline 2008 & $\begin{array}{l}\text { Your Health Your Life: Healthcare Reform Consultation } \\
\text { Document 1st Stage Consultation }\end{array}$ & 2 & 2 & 2 & 2 & 8 & 12 & 0.67 \\
\hline 2010 & $\begin{array}{l}\text { My Health My Choice: Healthcare Reform Second Stage } \\
\text { Consultation Document 2nd Stage Consultation }\end{array}$ & 2 & 2 & 2 & 2 & 8 & 12 & 0.67 \\
\hline \multirow[t]{4}{*}{2014} & Voluntary Health Insurance Scheme: Consultation Document & 2 & 2 & 2 & 2 & 8 & 12 & 0.67 \\
\hline & INDICATIVE SCORES & 14 & 13 & 13 & 12 & 52 & 84 & 0.62 \\
\hline & MAXIMUM INDICATIVE SCHOOLS & 21 & 21 & 21 & 21 & 84 & & \\
\hline & LAUNCH-READINESS INDEX & 0.67 & 0.62 & 0.62 & 0.57 & 0.62 & & \\
\hline
\end{tabular}


Appendix 3: Indicative and index scores of tasks performance under work domain - reform goals and objectives, by consultation document

\begin{tabular}{|c|c|c|c|c|c|c|c|c|}
\hline \multirow[b]{2}{*}{$\begin{array}{c}\text { YEAR } \\
\text { RELEASED }\end{array}$} & \multirow[b]{2}{*}{ DOCUMENT OR STUDY IITLE } & \multicolumn{7}{|c|}{ 2. REFORM GOALS AND OBJECTIVES } \\
\hline & & $\begin{array}{l}\text { POLLCY OR } \\
\text { GUIDING OF } \\
\text { REFRM } \\
\text { EXPLAINED }\end{array}$ & $\begin{array}{l}\text { REFORM GOALS } \\
\text { OBJECTIVES OR } \\
\text { IAREST } \\
\text { EXPLAINED }\end{array}$ & $\begin{array}{l}\text { RESOURCE } \\
\text { ALLOCATION } \\
\text { OR PROVIDER } \\
\text { PAYMENT } \\
\text { METHODS } \\
\text { OUTLINED }\end{array}$ & $\begin{array}{l}\text { INSTITUTIONAL } \\
\text { ARRANGEMENTS } \\
\text { TOAUGMENT } \\
\text { IMPLEMENTATION } \\
\text { OUTLINED }\end{array}$ & $\begin{array}{l}\text { INDICATIVE } \\
\text { SCORES }\end{array}$ & $\begin{array}{l}\text { MAXIMUM } \\
\text { INDICATIVE } \\
\text { SCORES }\end{array}$ & $\begin{array}{l}\text { LAUNCH } \\
\text { READNESS } \\
\text { INDEX }\end{array}$ \\
\hline 1993 & $\begin{array}{l}\text { Towards Better Health: A Consultation Document } \\
\text { (The Rainbow Document) }\end{array}$ & 1 & 1 & 0 & 1 & 3 & 12 & 0.25 \\
\hline \multirow[t]{2}{*}{1999} & $\begin{array}{l}\text { Improving Hong Kong's Health Care System: } \\
\text { Why and For Whom? (The Harvard Report) }\end{array}$ & & & & & & & \\
\hline & 1st Stage Consultation & 2 & 2 & 1 & 2 & 7 & 12 & 0.58 \\
\hline 2000 & $\begin{array}{l}\text { Lifelong Investment in Health: A Consultation Document } \\
\text { on Health Care Reform 2nd Stage Consultation }\end{array}$ & 1 & 1 & 0 & 1 & 3 & 12 & 0.25 \\
\hline 2004 & $\begin{array}{l}\text { A Study on Health Care Financing and Feasibility } \\
\text { of a Medical Savings Scheme in Hong Kong }\end{array}$ & 2 & 1 & 0 & 1 & 4 & 12 & 0.33 \\
\hline 2005 & $\begin{array}{l}\text { Building a Healthy Tomorrow: Discussion Paper on the } \\
\text { Future Service Delivery Model for our Health Care System }\end{array}$ & \multicolumn{7}{|c|}{$\begin{array}{l}\text { The document is not analyzed because it is about service delivery reform, } \\
\text { NOT healthcare financing reform. }\end{array}$} \\
\hline 2008 & $\begin{array}{l}\text { Your Health Your Life: Healthcare Reform Consultation } \\
\text { Document 1st Stage Consultation }\end{array}$ & 1 & 1 & 0 & 1 & 3 & 12 & 0.25 \\
\hline 2010 & $\begin{array}{l}\text { My Health My Choice: Healthcare Reform Second Stage } \\
\text { Consultation Document } 2 \text { 2nd Stage Consultation }\end{array}$ & 1 & 1 & 1 & 1 & 4 & 12 & 0.33 \\
\hline 2014 & Voluntary Health Insurance Scheme: Consultation Document & 2 & 2 & 2 & 1 & 7 & 12 & 0.58 \\
\hline & INDICATIVE SCORES & 10 & 9 & 4 & 8 & 31 & 84 & 0.37 \\
\hline & MAXIMUM INDICATIVE SCHOOLS & 21 & 21 & 21 & 21 & 84 & & \\
\hline & LAUNCH-READINESS INDEX & 0.48 & 0.43 & 0.19 & 0.38 & 0.37 & & \\
\hline
\end{tabular}


Appendix 4: Indicative and index scores of tasks performance under work domain - anaysis of policy options and selection, by consultation document

\begin{tabular}{|c|c|c|c|c|c|c|c|c|}
\hline \multirow[b]{2}{*}{$\begin{array}{c}\text { YEAR } \\
\text { RELEASED }\end{array}$} & \multirow[b]{2}{*}{ DOCUMENT OR STUDY TITLE } & \multicolumn{7}{|c|}{ 3. ANALYSIS OF POLICY OPTIONS \& SELECTION } \\
\hline & & $\begin{array}{l}\text { PROS AND CONS } \\
\text { OR IMPACT } \\
\text { OF REFORM } \\
\text { OPTIONS } \\
\text { EXPLAINED }\end{array}$ & $\begin{array}{l}\text { PREEERRED } \\
\text { OPEITNSSI OR } \\
\text { DESLI } \\
\text { EXPLANED }\end{array}$ & $\begin{array}{l}\text { RATIONALE OR } \\
\text { CRIIERII OF } \\
\text { SELECTING } \\
\text { PROPOSED } \\
\text { OPPION(S) } \\
\text { EXPLAINED }\end{array}$ & $\begin{array}{l}\text { FEASIBILITY OR } \\
\text { RESOURCES } \\
\text { REQURED TO } \\
\text { ACHIEVE GOALS } \\
\text { AND OBEETIVES } \\
\text { DISCUSSED }\end{array}$ & $\begin{array}{l}\text { INDICAAIVE } \\
\text { SCORES }\end{array}$ & $\begin{array}{l}\text { MAXIMUM } \\
\text { INDICATIVE } \\
\text { SCORES }\end{array}$ & $\begin{array}{l}\text { LAUNCH } \\
\text { READINESS } \\
\text { INDEX }\end{array}$ \\
\hline 1993 & $\begin{array}{l}\text { Towards Better Health: A Consultation Document } \\
\text { (The Rainbow Document) }\end{array}$ & 2 & 1 & 1 & 1 & 5 & 12 & 0.42 \\
\hline \multirow[t]{2}{*}{1999} & $\begin{array}{l}\text { Improving Hong Kong's Health Care System: } \\
\text { Why and For Whom? (The Harvard Report) }\end{array}$ & & & & & & & \\
\hline & 1st Stage Consultation & 3 & 3 & 3 & 2 & 11 & 12 & 0.92 \\
\hline 2000 & $\begin{array}{l}\text { Lifelong Investment in Health: A Consultation Document } \\
\text { on Health Care Reform 2nd Stage Consultation }\end{array}$ & 1 & 1 & 1 & 0 & 3 & 12 & 0.25 \\
\hline 2004 & $\begin{array}{l}\text { A Study on Health Care Financing and Feasibility } \\
\text { of a Medical Savings Scheme in Hong Kong }\end{array}$ & 2 & 2 & 2 & 2 & 8 & 12 & 0.67 \\
\hline 2005 & $\begin{array}{l}\text { Building a Healthy Tomorrow: Discussion Paper on the } \\
\text { Future Service Delivery Model for our Health Care System }\end{array}$ & \multicolumn{7}{|c|}{$\begin{array}{l}\text { The document is not analyzed because it is about service delivery reform, } \\
\text { NOT healthcare financing reform. }\end{array}$} \\
\hline 2008 & $\begin{array}{l}\text { Your Health Your Life: Healthcare Reform Consultation } \\
\text { Document } 1 \text { st Stage Consultation }\end{array}$ & 2 & 1 & 2 & 1 & 6 & 12 & 0.50 \\
\hline 2010 & $\begin{array}{l}\text { My Health My Choice: Healthcare Reform Second Stage } \\
\text { Consultation Document } 2 \text { 2nd Stage Consultation }\end{array}$ & 2 & 2 & 1 & 1 & 6 & 12 & 0.50 \\
\hline 2014 & Voluntary Health Insurance Scheme: Consultation Document & 2 & 2 & 2 & 0 & 6 & 12 & 0.50 \\
\hline & INDICATIVE SCORES & 14 & 12 & 2 & 7 & 45 & 84 & 0.54 \\
\hline & MAXIMUM INDICATIVE SCHOOLS & 21 & 21 & 21 & 21 & 84 & & \\
\hline & LAUNCH-READINESS INDEX & 0.67 & 0.57 & 0.57 & 0.33 & 0.54 & & \\
\hline
\end{tabular}


Appendix 5: Indicative and index scores of tasks performance under work domain - advocay and public engagement, by consultation documents

\begin{tabular}{|c|c|c|c|c|c|c|c|}
\hline \multirow[b]{2}{*}{$\begin{array}{c}\text { YEAR } \\
\text { RELEASED }\end{array}$} & \multirow[b]{2}{*}{ DOCUMENT OR STUDY TITLE } & \multicolumn{6}{|c|}{ 4. ADVOCACY AND PUBLIC ENGAGEMENT } \\
\hline & & $\begin{array}{l}\text { GROUP(S) OR } \\
\text { COMMIITEE(S) } \\
\text { APPONTTEDT GIVE } \\
\text { INPUT OR ADVIICE }\end{array}$ & $\begin{array}{c}\text { WIDER } \\
\text { COMMUNIYY } \\
\text { EXPECTATIONS } \\
\text { ADDRESSED OR } \\
\text { SUPPORT } \\
\text { MOBLILSED }\end{array}$ & $\begin{array}{l}\text { REFORM ENGINE } \\
\text { SET UP TO DRIVE } \\
\text { IMPLEMENTATION }\end{array}$ & $\begin{array}{l}\text { INDICAAIVE } \\
\text { SCORES }\end{array}$ & $\begin{array}{l}\text { MAXIMUM } \\
\text { INDICATIVE } \\
\text { SCORES }\end{array}$ & $\begin{array}{l}\text { LAUNCH } \\
\text { READINESS } \\
\text { INDEX }\end{array}$ \\
\hline 1993 & $\begin{array}{l}\text { Towards Better Health: A Consultation Document } \\
\text { (The Rainbow Document) }\end{array}$ & 2 & 0 & 0 & 2 & 9 & 0.22 \\
\hline \multirow[t]{2}{*}{1999} & $\begin{array}{l}\text { Improving Hong Kong's Health Care System: Why and For Whom? } \\
\text { (The Harvard Report) }\end{array}$ & & & & & & \\
\hline & 1st Stage Consultation & 2 & 1 & 2 & 5 & 9 & 0.56 \\
\hline \multirow[t]{2}{*}{2000} & Lifelong Investment in Health: A Consultation Document on Health Care & & & & & & \\
\hline & Reform 2nd Stage Consultation & 1 & 0 & 1 & 2 & 9 & 0.22 \\
\hline \multirow[t]{2}{*}{2004} & A Study on Health Care Financing and Feasibility of a Medical Savings & & & & & & \\
\hline & Scheme in Hong Kong & 3 & 1 & 0 & 4 & 9 & 0.44 \\
\hline 2005 & $\begin{array}{l}\text { Building a Healthy Tomorrow: Discussion Paper on the Future Service } \\
\text { Delivery Model for our Health Care System }\end{array}$ & \multicolumn{6}{|c|}{$\begin{array}{l}\text { The document is not analyzed because it is about service delivery reform, } \\
\text { NOT healthcare financing reform. }\end{array}$} \\
\hline 2008 & $\begin{array}{l}\text { Your Health Your Life: Healthcare Reform Consultation Document } \\
\text { 1st Stage Consultation }\end{array}$ & 2 & 0 & 0 & 2 & 9 & 0.22 \\
\hline \multirow[t]{2}{*}{2010} & My Health My Choice: Healthcare Reform Second Stage Consultation & & & & & & \\
\hline & Document 2nd Stage Consultation & 2 & 0 & 0 & 2 & 9 & 0.22 \\
\hline \multirow[t]{4}{*}{2014} & Voluntary Health Insurance Scheme: Consultation Document & 2 & 0 & 0 & 2 & 9 & 0.22 \\
\hline & INDICATIVE SCORES & 14 & 2 & 3 & 19 & 63 & 0.30 \\
\hline & MAXIMUM INDICATIVE SCHOOLS & 21 & 21 & 21 & 63 & & \\
\hline & LAUNCH-READINESS INDEX & 0.67 & 0.10 & 0.14 & 0.30 & & \\
\hline
\end{tabular}

